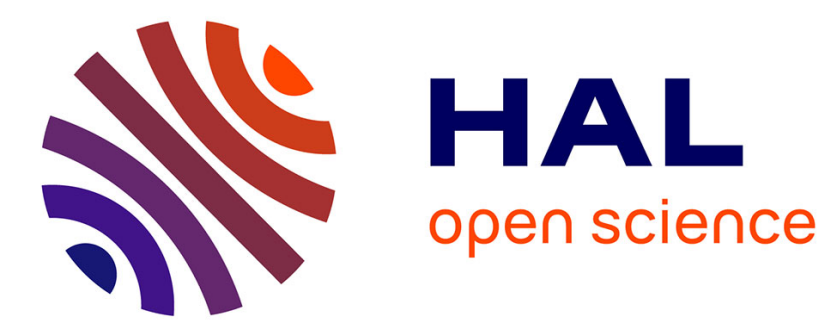

\title{
Seasonal and interannual variability of salinity in a large West-African lagoon (Nokoué Lagoon, Benin)
}

Victor Olaègbè Okpeitcha, Alexis Chaigneau, Yves Morel, Thomas Stieglitz, Yves Pomalegni, Zacharie Sohou, Daouda Mama

\section{- To cite this version:}

Victor Olaègbè Okpeitcha, Alexis Chaigneau, Yves Morel, Thomas Stieglitz, Yves Pomalegni, et al.. Seasonal and interannual variability of salinity in a large West-African lagoon (Nokoué Lagoon, Benin). Estuarine and Coastal Marine Science, 2021, 10.1016/j.ecss.2021.107689 . hal-03368397

\section{HAL Id: hal-03368397 https://hal.science/hal-03368397}

Submitted on 6 Oct 2021

HAL is a multi-disciplinary open access archive for the deposit and dissemination of scientific research documents, whether they are published or not. The documents may come from teaching and research institutions in France or abroad, or from public or private research centers.
L'archive ouverte pluridisciplinaire HAL, est destinée au dépôt et à la diffusion de documents scientifiques de niveau recherche, publiés ou non, émanant des établissements d'enseignement et de recherche français ou étrangers, des laboratoires publics ou privés. 
1 Seasonal and interannual variability of salinity in a large West-African

2

3 9

22

\section{lagoon (Nokoué Lagoon, Benin)}

\section{Victor Olaègbè OKPEITCHA ${ }^{1,2,3, *}$, Alexis CHAIGNEAU ${ }^{4,3,2}$, Yves MOREL ${ }^{4}$, Thomas STIEGLITZ $^{5}$, Yves POMALEGNI ${ }^{2}$, Zacharie SOHOU ${ }^{3,6}$, Daouda MAMA ${ }^{1}$}

${ }^{1}$ Laboratoire d'Hydrologie Appliquée (LHA), Institut National de 1'Eau (INE), African Centre of Excellence for Water and Sanitation (C2EA), Université d'Abomey Calavi, Bénin

${ }^{2}$ International Chair in Mathematical Physics and Applications (ICMPA-UNESCO

Chair)/University of Abomey- Calavi, Cotonou, Benin

${ }^{3}$ Institut de Recherches Halieutiques et Océanologiques du Bénin (IRHOB), Cotonou, Benin,

${ }^{4}$ Laboratoire d'Études en Géophysique et Océanographie Spatiale (LEGOS), Université de Toulouse, CNES, CNRS, IRD, UPS, Toulouse, France

${ }^{5}$ Aix-Marseille Université, CNRS, IRD, INRAE, Coll France, CEREGE, Aix-en-Provence, France

${ }^{6}$ Département de Zoologie, Faculté des Sciences et Techniques (FAST/UAC), Bénin

(1)

*Corresponding author : Victor Olaègbè OKPEITCHA, vokpeitcha@ gmail.com 


\section{Abstract}

Nokoué Lagoon in the South of Benin is a large intermittent coastal water body in West Africa, which supports one of the largest inland fisheries of the region. The seasonal and interannual variability of its salinity was studied, based on 3 years of monthly surveys (Dec 2017 - Dec 2020). This dataset allows us to identify fine-scale salinity structures and to better understand the salinization/desalinization processes at seasonal scales. During the rainy season from May to November, under the influence of large freshwater inflows from the rivers on its northern shores, the lagoon desalinizes to a salinity of zero in October-November. During the dry season from December to April, under the effect of the ocean tide, Nokoue lagoon becomes progressively saltier, reaching typical salinities of $\sim 25$ in April. On average, the Nokoué lagoon is saltier in its southwestern part and fresher towards the river's mouths.

Vertical salinity stratification is largest in December at the beginning of the main dry season. The lagoon displays a very marked interannual variation with mean surface (bottom, respectively) salinity of 25 (25) in April 2018 and 2020, respectively, against 16 (18) in April 2019. In the absence of river inflow data, a box model shows that the average salinity of the lagoon is very sensitive to small changes in river inflow (or discharge), with observed interannual differences in salinity induced by small variations of $10-15 \mathrm{~m}^{3} \mathrm{~s}^{-1}$ in inflow during the dry season. During the salinization phase, the model suggests that $\sim 30 \%$ of the seawater entering the lagoon during flood-tides remains trapped and enhances the Nokoué lagoon salinity. This model also indicates that a complete desalinization of the lagoon occurs for river inflow greater than $\sim 50-60 \mathrm{~m}^{3} \mathrm{~s}^{-1}$. The general mixing time scale of the lagoon is of $30-40$ days.

Keywords: Salinity; tropical lagoon; Nokoué lagoon; seasonal and interannual variations; stratification; box model. 


\section{Introduction}

Lake Nokoué is located in South Benin (Fig. 1) between $6.33^{\circ} \mathrm{N}$ and $6.50^{\circ} \mathrm{N}$ and $2.33^{\circ} \mathrm{E}$ and $2.58^{\circ} \mathrm{E}$. It extends over a maximum of $\sim 11 \mathrm{~km}$ from South to North, and of $\sim 20$ $\mathrm{km}$ from West to East, covering an area of $\sim 150 \mathrm{~km}^{2}$ during low-water periods (Gadel and Texier, 1986; Le Barbé et al., 1993). The lake is the largest body of water in Benin (Lalèyè et al., 2003; Le Barbé et al., 1993) and the most productive in West Africa in terms of fish resources (Badahoui et al., 2009; Gnohossou et al., 2013). Exploited by 40000 fishermen, it is the largest contributor to Benin's continental fisheries and thus contributes to food security and socio-economic development. Lake Nokoué is subject to strong anthropogenic pressures. Indeed, it not only hosts the largest lacustrine villages of West Africa (Djihouessi and Aina, 2018; Yehouenou et al., 2013) but is also surrounded by the largest cities of South Benin with a population exceeding 1.5 million inhabitants (Gnohossou, 2006). Lake Nokoué is also part of the Lagos (Nigeria) - Accra (Ghana) urban corridor made up of more than 2000 urban agglomerations totalizing 30 million people today with a future projection of 50 million inhabitants by 2050 (Choplin, 2019; Moriconi-Ebrard et al., 2016).

Lake Nokoué lies in a transition zone between the large catchment areas of the Ouémé River in the north-east and the Sô River in the north-west, and the Atlantic Ocean, with which it communicates through the $4.5 \mathrm{~km}$ long and $\sim 300 \mathrm{~m}$ wide artificial Cotonou channel (Le Barbé et al., 1993; Mama et al., 2011) (Figure 1). As a result of its permanent connection with the Atlantic Ocean since construction of the channel, the previously unconnected 'Lake' Nokoué (as it is still known in colloquial language) is today an extensive lagoon and is thus hereinafter referred as Nokoué Lagoon. Nokoué Lagoon also communicates in its western part with the small Djonou River (a few meters wide and a few kilometers long) and in the east with the Porto-Novo lagoon via the Totchè canal (Fig. 1), but they have little effect on the 
dynamics of Nokoué Lagoon (Texier et al., 1980; Le Barbé et al., 1993; Chaigneau et al., 2021).

In Northern Benin, where the Ouémé River originates, the climate is tropical, characterized by a single rainy season that extends from April to October, with maximum rainfall in August and September (Gadel and Texier, 1986; N'Tcha M'Po et al., 2017; Djihouessi and Aina, 2018). In the south, the climate is sub-equatorial and characterized by two rainy seasons: a long rainy season that extends from April-May to July and a short season that extends from September to November (Gadel and Texier, 1986; Djihouessi and Aina, 2018). During the short rainy season of South Benin, which coincides with the rainy season in North Benin, the Ouémé and Sô rivers are in flood and discharge a large amount of fresh water into Nokoué lagoon (Gadel and Texier, 1986; Djihouessi and Aina, 2018). The maximum discharge into the lagoon between September and November is badly known (rivers not regularly gauged in the coastal region), but some studies reported maximum river fluxes varying, depending on authors, from $\sim 400 \mathrm{~m}^{3} \mathrm{~s}^{-1}$ (Le Barbé et al., 1993; Djihouessi and Aina, 2018) to more than $1000 \mathrm{~m}^{3} \mathrm{~s}^{-1}$ (Lawin et al., 2019). The mean water level in the lagoon, which is of $\sim 1.3 \mathrm{~m}$ in dry season (Figure 1c), increases by up to $\sim 90 \mathrm{~cm}$ during river floods to reach an average value of $\sim 2.20 \mathrm{~m}$ (Chaigneau et al., 2021). In contrast, the period from December to April corresponds to the dry season in southern Benin, during which river flow is minimal (a few tens of $\mathrm{m}^{3} \mathrm{~s}^{-1}$ ) and the lagoon depth decreases to an average of $1.30 \mathrm{~m}$ (Lalèyè et al., 2003; Niyonkuru and Lalèyè, 2010; Chaigneau et al., 2021; see also Fig. 1c). 


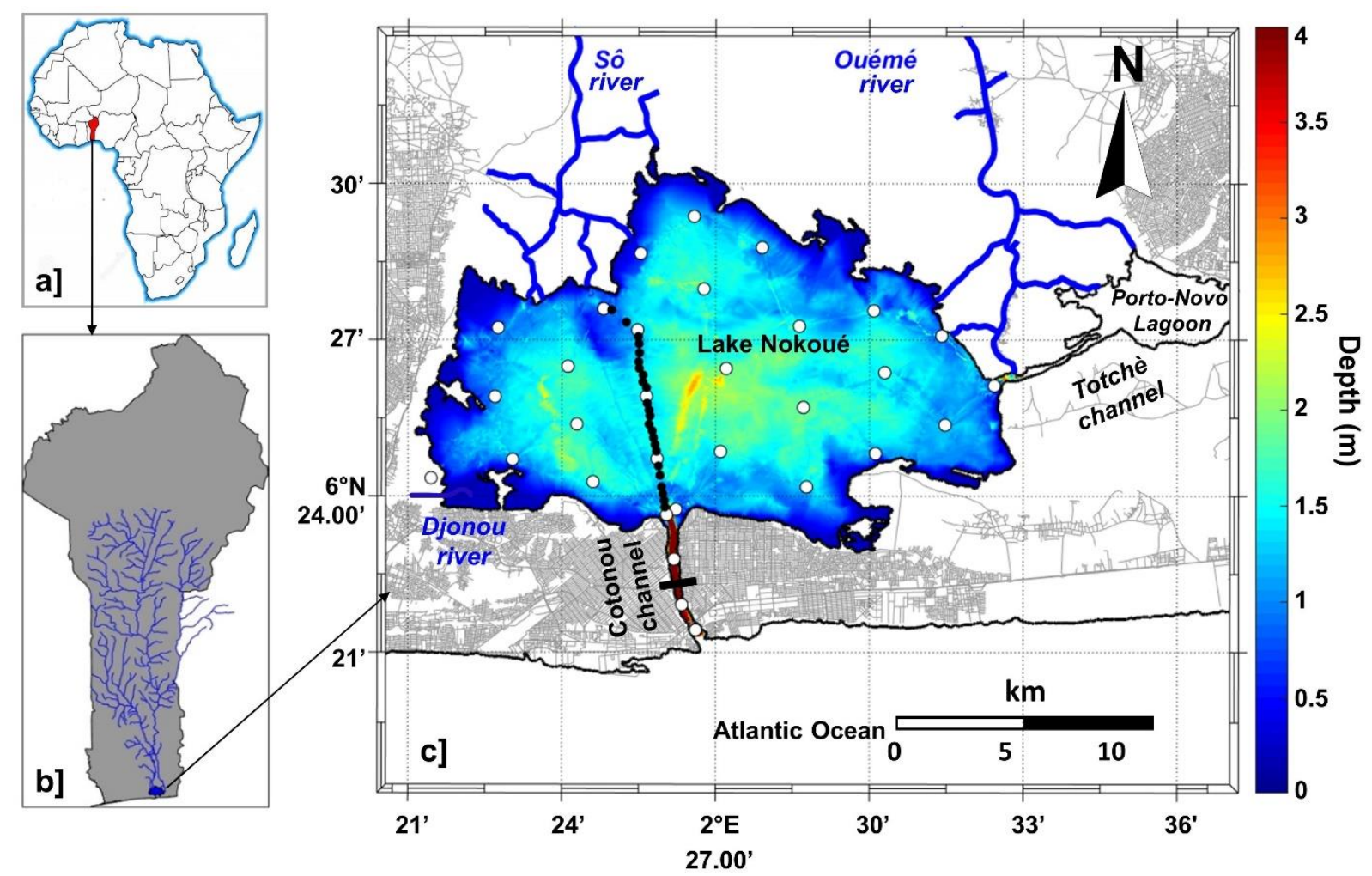

Fig. 1. Location of Nokoué lagoon (Benin) and hydrographic stations carried out between December 2017 and December 2020. a] Benin location in West-Africa. b] Hydrographic network of the Sô and Ouémé catchments in Benin; c] White dots represent the 31 CTD stations occupied monthly; black dots represent the 24 additional CTD stations occupied monthly in December 2017 and between February and December 2018; color shading represents the bathymetry during low water season. Black line across the Cotonou channel represents the repetitive cross-section occupied for ADCP measurements.

One of the key parameters of estuarine and lagoon environments is salinity, which greatly conditions the composition and structuring of ecosystems (Attrill, 2002). The salinity of Nokoué lagoon and its spatial and temporal variations are induced at first order by the exchange of fresh water from the rivers (mainly Sô and Ouémé) and seawater entering the lagoon via the Cotonou channel under the effect of the ocean tide (Le Barbé et al., 1993; Mama, 2010; Zandagba et al., 2016b). From numerical simulations, typical tidal inflows and outflows in the Cotonou channel have been estimated to $400-1000 \mathrm{~m}^{3} \mathrm{~s}^{-1}$, depending on the considered tidal period (neap or spring tides) and hydrological season (dry or wet) (Zandagba 
et al., 2016b). During high-water periods (September to November), Nokoué lagoon is filled with fresh water and has zero salinity (Djihouessi and Aina, 2018; Mama et al., 2011; Zandagba et al., 2016b). In contrast, during low-water periods the lagoon gradually becomes saltier and salinity varies from 28 North of the Cotonou channel, to 5 close to the river mouths (Djihouessi and Aina, 2018; Mama, 2010; Mama et al., 2011; Zandagba et al., 2016a). Nokoué lagoon is therefore subject to significant variations in salinity on seasonal scales, which impacts the composition and distribution of the ecosystem from planktonic species or macroinvertebrates (Adandedjan et al., 2017; Le Barbé et al., 1993; Odountan et al., 2019) to fish (Lalèyè et al., 2003). Seasonal variations of salinity in Nokoué lagoon are therefore very important for ecosystem structuring but can also contribute to the salinization of the underlying aquifer which is used to supply drinking water to the cities of Porto-Novo and Cotonou (Alassane et al., 2015; Dovonou and Boukari, 2014). Salinization of the lagoon during low-water periods also contributes to the periodic reduction of water hyacinth cover, a prolific invasive plant present in large and increasing quantities during freshwater periods (Mama, 2010; Mama et al., 2011).

Although salinity variations in Nokoué lagoon have been previously described at seasonal scales (Djihouessi and Aina, 2018; Mama et al., 2011; Zandagba et al., 2016a), a thorough analysis is still lacking and the data used in these previous studies present some limitations. First, observations of salinity variations were discussed based on a limited number (3-5) of sampling stations within the lagoon (Gnohossou, 2006; Lalèyè et al., 2003), followed by studies which included 10-20 stations (Adandedjan et al., 2017; Djihouessi and Aina, 2018; Zandagba et al., 2016a). Second, in all these studies, data were systematically acquired during a limited period of time of one (Gnohossou, 2006; Lalèyè et al., 2003; Zandagba et al., 2016a) or two years (Mama et al., 2011), and the frequency of acquisition varied from monthly observations to only few field campaigns per year. Third, the vertical salinity structure and 
stratification were barely discussed since salinity data were mainly acquired at the water surface. Finally, among these 4 studies, only Djihouessi and Aina (2018) show spatial maps of surface salinity allowing to identify frontal structures and horizontal salinity gradients.

In this study, based on 3 years of salinity data (2018-2020) acquired during 37 monthly surveys, the seasonal and interannual variability of both the surface and bottom salinity in Nokoué lagoon are examined. Monthly maps, together with high-resolution north-south sections realized across the lagoon allow us to highlight fine-scale salinity structures and better understand the salinization/desalinization processes that take place at the beginning of the low- and high-water periods. In the absence of river inflow data, a simple box model is further used to improve our understanding of the observed salinity changes.

\section{Data and methods}

Between December 2017 and December 2020, physical parameters of Nokoué lagoon and the Cotonou channel were sampled in monthly intervals. During each survey, 31 vertical temperature and salinity profiles were acquired using a Conductivity Temperature Depth (CTD) probe (Valeport MIDAS CTD+ 300) deployed from the surface to the bottom (white dots in Figure 1b). In December 2017 and between February and December 2018, high spatial resolution north-south sections were also recorded between the Cotonou channel and the mouth of the Sô River (Fig. 1b). These sections consisted of 24 additional hydrographic stations in $250 \mathrm{~m}$ intervals, allowing us to document and monitor the monthly evolution of the salt front and vertical stratification across the main (hydrological) axis of the lagoon.

The CTD acquisition frequency was $8 \mathrm{~Hz}$ and the parameters were recorded every 0.1 dbar $(\sim 10 \mathrm{~cm})$ between the surface and the bottom, which the depth typically varies between $0.5 \mathrm{~m}$ and $2.5 \mathrm{~m}$ (Figure 1c). Only the descent CTD profiles were used. For each monthly survey, salinity data from the 31 stations were spatially interpolated onto a regular grid of 
$\sim 100 \mathrm{~m}$ x $100 \mathrm{~m}$ resolution, using an objective interpolation scheme (Bretherton et al., 1976; McIntosh, 1990; Wong et al., 2003). Note that salinity was measured using the Practical Salinity Scale, with no units (see Millero, 1993, and UNESCO recommendations, 1985).

In order to interpret the observed salinity variations between 2018 and 2020, exchanges of water between the Atlantic Ocean and the lagoon were monitored across the Cotonou channel (see black line in Fig. 1c) at monthly intervals between August 2019 and December 2020, using an acoustic Doppler current profiler (ADCP Teledyne RDI WorkHorse $1200-\mathrm{kHz}$ ), mounted on the side of a small wooden boat. Vertical profiles of velocity data were collected at $1 \mathrm{~s}$ intervals using WinRiver II software (RDI Teledyne) with GPS positioning and bottom-tracking. For each transect, the total inflow-outflow transport across the Cotonou channel was calculated by integrating velocity profiles throughout the wet crosssection. Among the 17 monthly ADCP field campaigns, we only retained the ones collected over more than 12 hours, providing inflow-outflow transport estimates during entire semidiurnal tidal cycles. Since we are interested in estimating these transports during the salinization period when the lagoon's water-level is relatively low and river inflow relatively weak (see below and Section 4.1), we also excluded the 6 ADCP campaigns realized in September-November of 2019 and 2020, when the river outflows were high. Each of the 10 ADCP field campaigns retained in this study consisted of 100-200 repetitive cross-sections that were occupied during $12-25 \mathrm{~h}$.

Together with a box model, this ADCP dataset is used in Section 4.1 to estimate the fraction of seawater that enters the lagoon during flood-tide and remains trapped within the lagoon. In order to relate the tidal flow variations observed in the Cotonou channel from ADCP data, to the tidal amplitude in the offshore ocean, we used tide elevations (amplitude and phase) computed from the last Finite Elements Solution for ocean tide (FES2014) on a $1 / 16^{\circ} \times 1 / 16^{\circ}$ grid (http://www.aviso.altimetry.fr/en/data/products/auxiliary-products/global- 
tide-fes.html) (Carrere et al. 2016; Lyard et al. 2020). Sea-level anomaly timeseries were reconstructed off Cotonou using the 34 tidal constituents (amplitudes and phases) computed from FES2014, and tidal amplitudes were then extracted from this timeseries for each of the 10 ADCP field campaigns.

We also used the Climate Hazards group Infrared Precipitation with Stations (CHIRPS) dataset (https://data.chc.ucsb.edu/products/CHIRPS-2.0/). This gridded product consists to rainfall estimates from blended rain gauge and satellite observations (Funk et al., 2015). Terrestrial precipitation estimates are distributed on a $0.05^{\circ} \times 0.05^{\circ}$ longitude/latitude grid and are available at daily to annual timeseries. We here used the decadal product, consisting of precipitation data every 10 days from January 2018 to December of 2020.

\section{Results}

\subsection{Spatiotemporal variability of surface salinity}

Figure $2 \mathrm{a}$ shows the monthly variability of surface salinity in Nokoue lagoon since December 2017, illustrating considerable seasonal variations. After a complete flushing of the lagoon in the main wet season, freshwater inflow is greatly reduced at the beginning of the main dry season in December, and seawater begins to enter the lagoon under the effect of the tide through the Cotonou channel. This results in saline intrusion first observed in the west of the lagoon. From January to April 2018, the lagoon is in a low-water period and gradually becomes saltier. Salinity is consistently highest near the mouth of the channel, and lowest close to the mouths of the rivers Sô (North-West), Ouémé (East-North-East) and Djonou (South-West). From May to August 2018, the lagoon desalinizes rapidly and reaches very low salinity values in July-August, at the end of the main rainy season in southern Benin. During 
this period, the western part of the lagoon remains saltier than the east. This salinity difference between the West and the East of the lagoon is $\sim 8$ in June-July and $\sim 4$ in August. During the flood period (September to November), the lagoon is almost entirely fresh. Its salinity is almost 0 during this period, and a substantial freshwater inflow inhibits any salt water intrusion from the ocean. In December 2018, the main dry season begins once again: seawater begins to penetrate into the lagoon again and a new cycle of salinization and desalination begins.

Seasonal salinity variations exhibit regular patterns during the 3-year study period (2018-2020) (Fig. 2a). Each year, from January to March-April, a gradual increase in salinity is observed, reaching maximum values in April. The south/south-west of the lagoon is systematically saltier, while the lowest salinity values systematically observed at the mouths of the Sô, Ouémé and Djonou rivers. From May to August, the lagoon becomes desalinated and a marked salinity gradient appears between the West and the East of the lagoon. From September to November, the surface of the lagoon is entirely filled with fresh water.

Despite the overall regular patterns, an interannual variability is evident. While the surface salinity values observed at the end of the low-water period in April 2018 and April 2020 are very similar, the overall salinity in April 2019 is significantly lower, in particular in the East of the lagoon during the entire low-water period. The maximum observed salinity value in April 2019 was 22, while it was 28 in April 2018 and 2020. Similarly, the minimum salinity value observed at the mouth of the Ouémé River during the same month was 20 in 2018 and 2020, and only 6 in 2019. Other differences can be observed on these maps. For instance, the months of July-August were slightly saltier in 2018 than the following years, whereas September and November 2020 were also saltier than in 2018 and 2019. More noticeable, December 2019 was much less salty than December 2017, 2018 and 2020. 


\subsection{Spatiotemporal variability of bottom salinity and lagoon}

\section{stratification}

Figure $2 \mathrm{~b}$ shows monthly variations of salinity at the bottom of the lagoon, typically varying from $0.5 \mathrm{~m}$ to $2.5 \mathrm{~m}$ in depth depending on the station (see also Fig. 1c) and the season. Overall, the salinity variations are comparable to those observed at the surface. The onset of a saline intrusion is observed in December. From January to April, the intrusion intensifies, with high salinity values observed at the end of the dry season (March-April). From May onwards, the salinity at the bottom decreases until it reaches very low values in July-August with a tendency to be saltier at the south-west of the lagoon. During the flood period between September and November, the lagoon bottom is fresh, except in 2020 when the saline intrusion started earlier in November. An interannual variability similar to that at the surface is observed.

To investigate the vertical stratification, we consider the salinity difference between the bottom and the surface as a measure of the vertical stratification in this very shallow lagoon (Fig. 2c).

From January to February 2018, the stratification gradually decreases. From March to June 2018, the salinity is vertically homogeneous. In July-August 2018, at the end of the main wet season in Cotonou, there is a slight increase of stratification, still in the southwest of the lagoon, but of less intensity than in December-January. In September-November, the lagoon is fresh from the surface to the bottom and thus no vertical stratification present (Fig. 2c).

In January-February 2019, the vertical stratification is less than in 2018 (Fig 2c). This relatively weaker stratification, associated with mean salinity differences of 2- 4 between the bottom and the surface, but locally reaching more than 10, continues from February to May 2019. In 2019, salinity becomes homogeneous vertically only during the flood period between August and November. In December 2019, stratification reaches a maximum with salinity 
differences of 15-18 between the surface and the bottom over most of the lagoon. This very strong stratification is maintained at the beginning of 2020 and then rapidly decreases as in 2018. In 2020, a pulse of high stratification was observed in September close to the Cotonou channel, and the salinization of the lagoon at the bottom began earlier in November than in other years (Figs. 2b-c). In contrast to December 2018, the maximum vertical stratification observed in December 2017, 2019 and 2020 is not only located in the southwest but extends over most of the lagoon. However, it remains very low at the mouths of the rivers compared to the whole lagoon. 


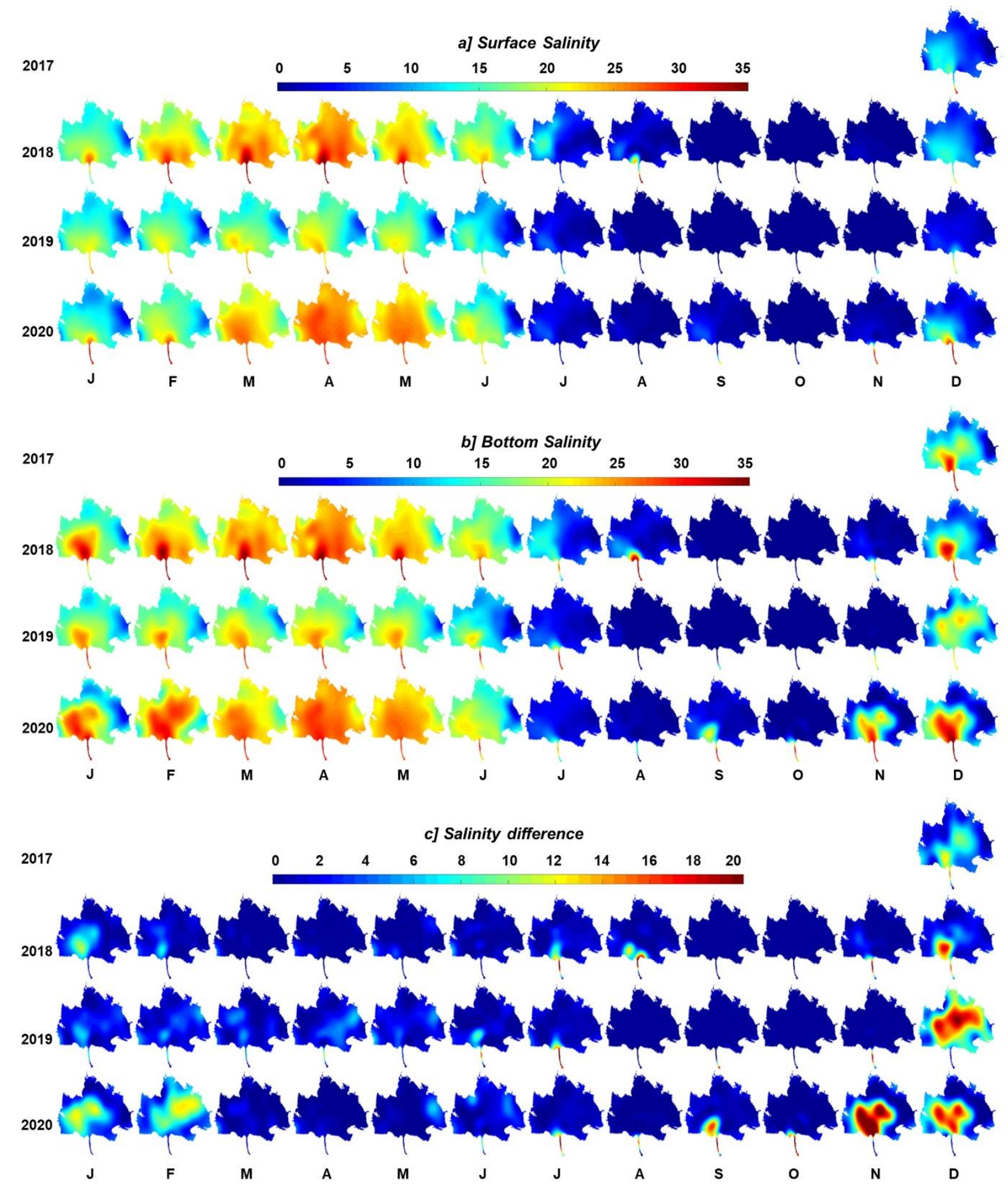

Fig. 2. Monthly variation in the Nokoué lagoon between December 2017 and December 2020 of a] surface salinity, b] bottom salinity and c] vertical salinity stratification. The stratification is here defined as the salinity difference between the bottom and the surface. 
Note that stratification also depends on temperature distribution. At seasonal scale, the water temperature varies from $26-28^{\circ} \mathrm{C}$ from June to October, to $31-32^{\circ} \mathrm{C}$ in March-April (not shown). In September-November, during high-water period, when the lake is desalinated, temperature differences between the surface and the bottom are maximum and can reach $1.5^{\circ} \mathrm{C}$. During the rest of the year, vertical temperature differences are less than $0.5^{\circ} \mathrm{C}$, but lagoon temperature is subject to a relatively strong diurnal cycle of $\sim 2^{\circ} \mathrm{C}$, due to surface heating by solar insolation. As horizontal and vertical temperature variations are significantly weaker than salinity variations, we here consider only salinity variations in order to assess the water column's vertical structure.

\subsection{High spatial resolution of the salt-wedge}

The high-resolution salinity sections recorded between the south and north of the lagoon clearly show that the salinity exhibits a classical wedge-shaped distribution at the beginning of the salinization and desalination periods (Fig. 3). This salt-wedge characteristic is related to the presence of gravity currents associated with the difference in density between fresh and salt water, and of weak vertical mixing despite the shallow depth (Fig. 1c) of the lagoon. In December 2017, a highly saline bottom layer was observed in the south of the lagoon with salinities of around 30 reaching latitude $6.42^{\circ} \mathrm{N}$. In this region, the difference in salinity between the bottom and the surface was about 15 . North of latitude $6.42^{\circ} \mathrm{N}$, salinity drops considerably throughout the water column and stratification weakens northward. To the north of the section, near the mouth of the Sô river, the water column is relatively homogeneous and desalinated, with salinity differences of $\sim 2$ between the bottom and the surface. In February 2018, the saline intrusion has intensified and extends to the North of the lagoon, but the salinity difference between the bottom and the surface has been reduced and is only $\sim 5$ South of latitude $6.42^{\circ} \mathrm{N}$. 
In March-April 2020, the salt-wedge has disappeared, and the water column is homogeneously salty between the surface and the bottom. Salinity decreases from the entrance of the channel $(\sim 35)$ to the mouth of the Sô river where salinities of around 25 are observed at this period of the year. In May-June, salinity decreases over the entire water column and the inflow of water from the Sô pushes the salinity front southwards. A stratification begins to reappear between $6.41^{\circ} \mathrm{N}$ and $6.43^{\circ} \mathrm{N}$ again in the form of a weak saltwedge (bottom-surface salinity differences $\sim 3$ ).

In July 2018, the section is mostly filled with relatively fresh water (salinity values < 12) but lenses of salt water are still present on the bottom. Somewhat counter-intuitive, salinity was also higher close to the Sô River than further South during this period. This is due to the recirculation of a lens of saltier water observed in the south-west of the lagoon and which flows northeastward along the northern shoreline of the lagoon (Figs. 2a-b). In August 2018, North of $6.41^{\circ} \mathrm{N}$, salinity is vertically homogeneous and the lagoon is almost desalinated (salinity values < 4). However, seawater penetrates from the South, and a very strong salinity front is formed with a difference in salinity between the bottom and the surface of about 10 (see also Fig. 2c).

From September to November, no stratification is observed along the South-North section. As described above, the entire water column is homogeneous and filled with fresh water and the lagoon reaches its highest water level, with values of more than $2 \mathrm{~m}$. 

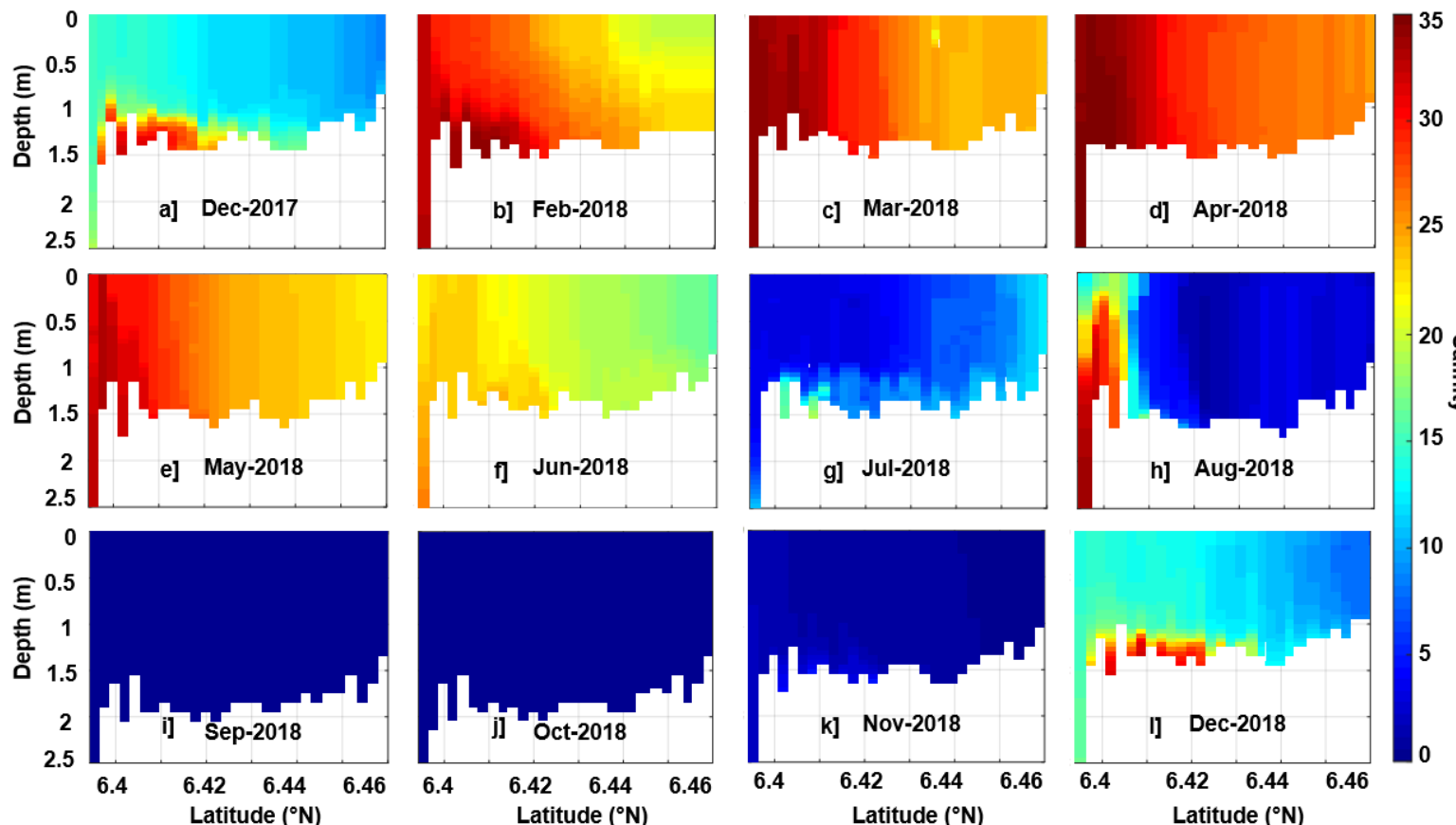

Fig. 3. Monthly evolution of the salinity along the high-resolution section occupied in the lagoon Nokoué between December 2017 (a]) and from February 2018 (b]) to December 2018 (l]). This South-North section crosses the lagoon from the entrance of the Cotonou channel to the mouth of the Sô river (see Fig.1c for the location of the transect).

\subsection{Interannual variability of the lagoon average salinity}

Surface and bottom salinity averaged over the lagoon exhibits large seasonal and interannual variations (Figure 4). Salinity increases rapidly from January to April, both at the surface and at the bottom, with maximum values observed in April. Salinity then decreases significantly from May to August during the main rainy season in South Benin, reaching zero values in September-November during the flood.

The annual maximum in surface and bottom salinity is significantly lower in April 2019 than in April 2018 and 2020. In September 2020, the lagoon was slightly saltier than at the same period in 2018 and 2019, with average salinity values of $\sim 2$ at the surface and $\sim 4$ at the bottom. In 2020, the flooding (increased river inflow) was delayed compared to previous years, which favored the entry of seawater into the lagoon via the Cotonou channel in 
September. In the same year, the saltwater intrusion started earlier in November in contrast to other years when the intrusion started in December.

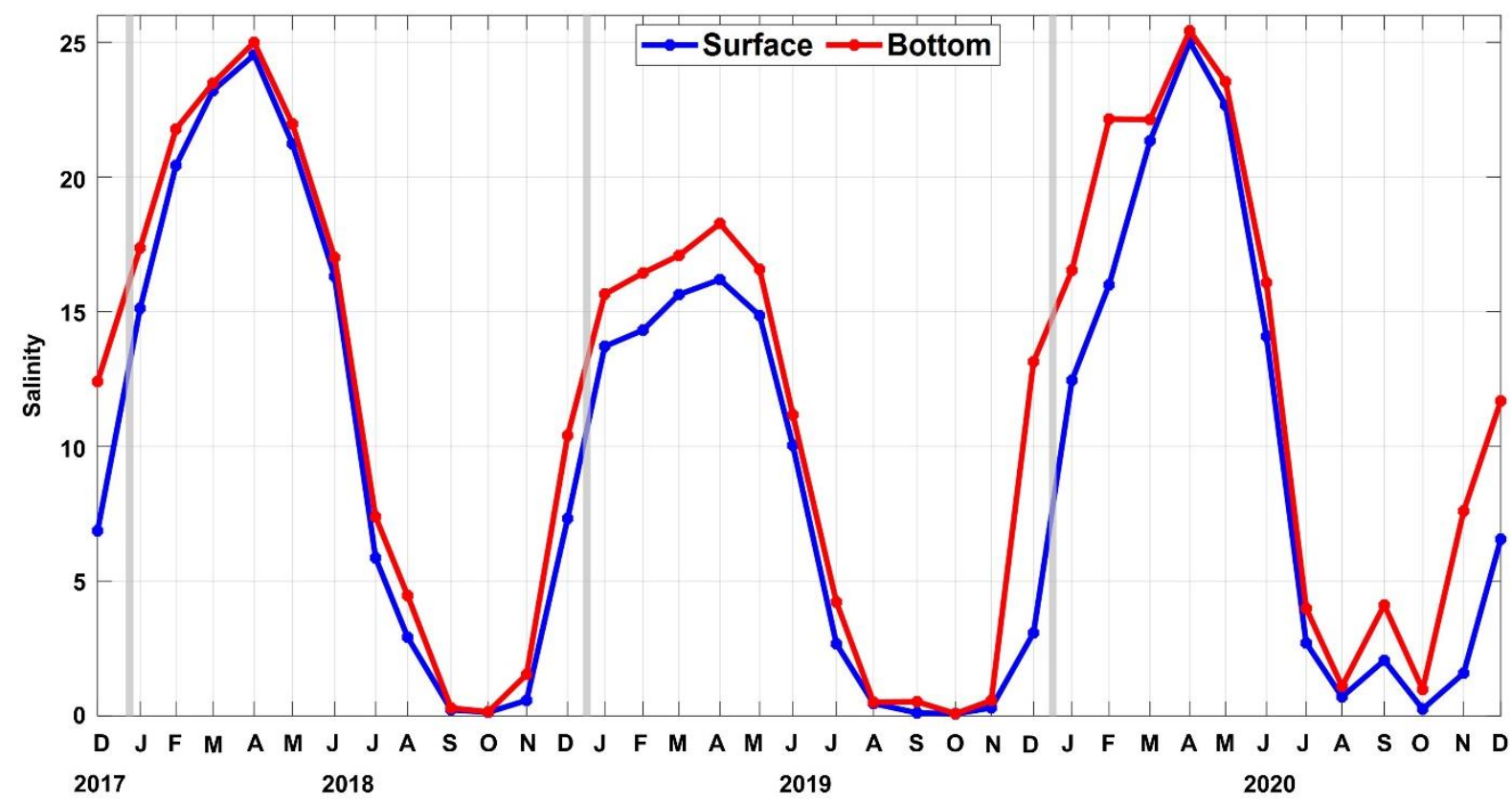

Fig. 4. Interannual variation of average surface and bottom salinity in the Nokoué lagoon between December 2017 and December 2020. Data from the Cotonou channel were excluded.

\section{Discussion}

In agreement with previous studies (Djihouessi and Aina, 2018; Mama, 2010; Mama et al., 2011; Zandagba et al., 2016a), our results show that the lagoon becomes saltier from December to April and then desalinates rapidly during the rainy seasons from May to November. Our study further shows that the salinization process of Nokoué lagoon begins in December, first at the bottom and southwest of the lagoon where a salt-wedge structure is observed. The salinization then spreads towards the northeast and the lagoon mixes vertically to become vertically homogeneous. Typical for coastal environments, the tide plays an important role during the salinization period as it regulates the exchange of waters with the ocean. Similarly, from May, the lagoon begins to desalinate first from the Northeast before 
this desalination gradually reaches the Southwest which remains saltier. Desalination is complete and the lagoon is filled with freshwater typically from August to November.

At first order, the average salinity of the lagoon results from a balance between i) the exchange of water between the ocean and the lagoon due to tides, and ii) the inflow of fresh water by the rivers. Thus, from the observed spatio-temporal salinity distributions, several questions at the scale of the Nokoué lagoon arise, namely:

i. what is the order of magnitude of the river inflow that is required to explain such strong salinization/desalinization with average salinities varying between 0 and $25 ?$

ii. what is the fraction of seawater that is trapped and mixed into the lagoon during each tidal cycle, in order to reach the high salinity levels observed during the dry season?

iii. what process can explain the observed salinity difference between the dry season of 2019 (salinity of $\sim 16$ ) and of 2018 and 2020 (salinity of $\sim 25$ )?

iv. Finally, at local scale, what process is responsible for the observed salinity gradient between the northeast and the southwest of the lagoon?

Unfortunately, because the Sô and Ouémé rivers are not regularly gauged, simultaneous river discharge and salinity data are not available for the study period. Climatological historical estimates indicate a total freshwater input to the lagoon that varies on average from a few tens of $\mathrm{m}^{3} \mathrm{~s}^{-1}$ from December to July and that reach $\sim 800 \mathrm{~m}^{3} \mathrm{~s}^{-1}$ between September and November (Chaigneau et al., 2021). Similarly, continuous and long-term monitoring of freshwater and saltwater exchanges between the lagoon and the ocean in the Cotonou Channel is not available. Thus, to address the above questions, we use a simple box model. 


\subsection{Key drivers of the lagoon salinity dynamics from a box model}

In order to better understand the salinity dynamics and to estimate important parameters for the salt cycle, we use a simple conceptual box model similar to the tidal prism model (de Miranda et al., 2017; Rynne et al., 2016). Figure 5 illustrates the exchange of water in the lagoon for both tidal phases (flow and ebb tides) when river outflows are relatively weak and seawater can penetrate the lagoon. During flood tide (Figs. 5a-b), we assume that only seawater, of salinity $\mathrm{S}_{0}$, enters the lagoon with an average inflow $\mathrm{F}_{\mathrm{T}}^{+}$. A fraction of this seawater mixes with fresher lagoon water, probably in the southwest part of the basin, and remains in the lagoon. During ebb tide (Figs. 5c-d), the mean outflow $\left(\mathrm{F}_{\mathrm{T}}^{-}\right)$transports i) a fraction $(1-\delta)$ of oceanic water which remains close to the mouth at the end of the flood tide (Fig. 5c), and ii) a fraction $\delta$ of lagoon water of salinity $\mathrm{S}_{\mathrm{L}}$ (Fig. 5d). Thus, $\delta$ represents the fraction of oceanic water that remains in the lagoon during the tidal cycle. Simultaneously during the whole tidal cycle, a continuous constant inflow of fresh water $\left(F_{R}\right)$ by the rivers ( $\left.F_{\text {Sô }}, F_{\text {Ouémé, }} F_{\text {Djonou }}\right)$ mixes with the lagoon water. 

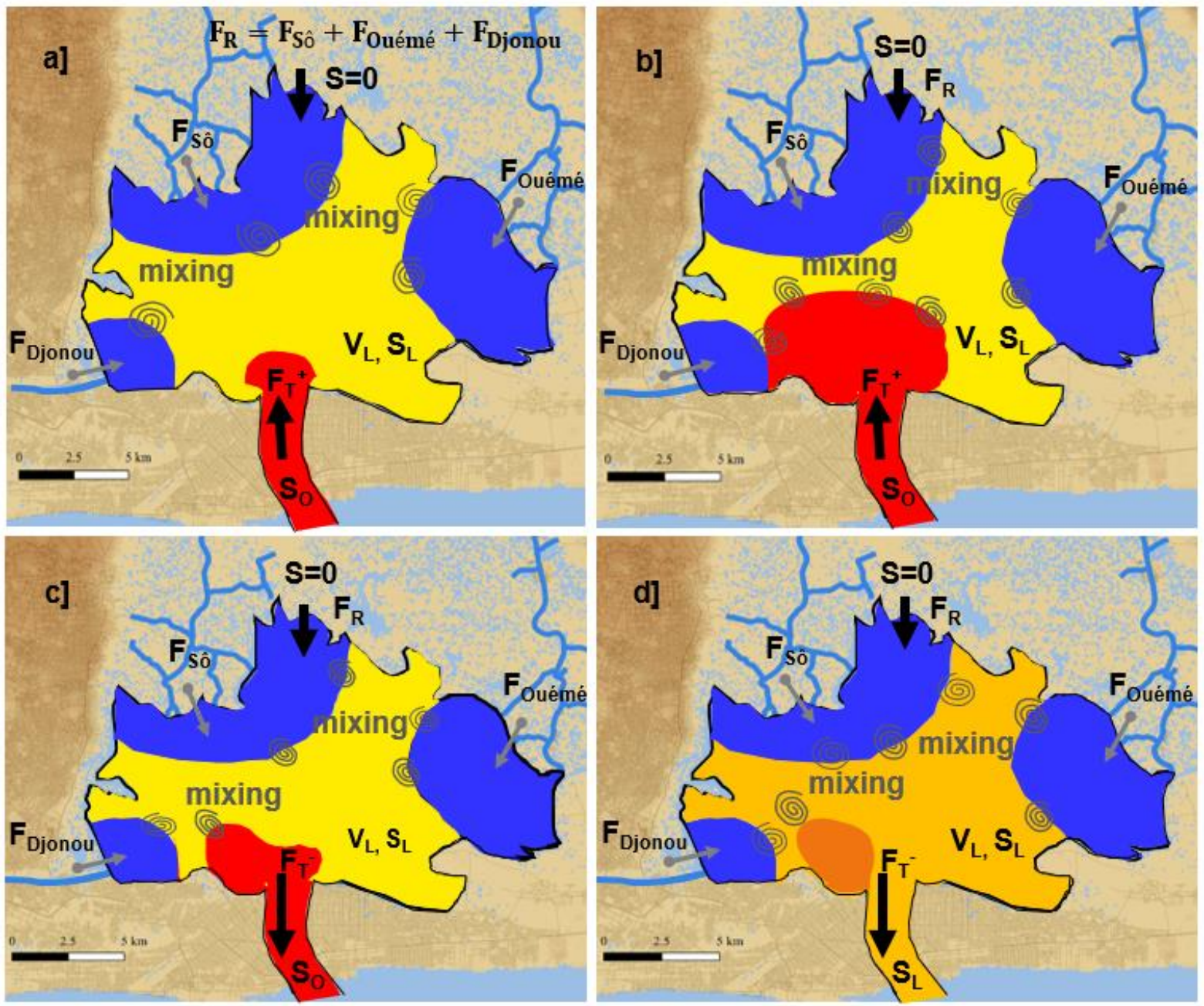

Fig. 5. Conceptual model of the effects of tides on the salinity of the Nokoue lagoon. a] Beginning of the flood-

392 tide b] End of the flood-tide. c] Beginning of the ebb-tide. d] End of the ebb-tide. $S_{0}$ and $S_{L}$ correspond to the lagoon and ocean salinity, respectively; $V_{L}$ is volume of the lagoon; $F_{R}$ is the river discharge whereas $F_{T}^{+}\left(F_{T}^{-}\right.$, respectively) corresponds to the inflow (outflow) during flood (ebb) tide.

Thus, during flood tide of duration $\mathrm{T}$ (for a semi-diurnal tide, $\mathrm{T} \sim 21600 \mathrm{~s}$ ), volume $\left(\mathrm{V}_{\mathrm{L}}\right)$ and salt $\left(\mathrm{S}_{\mathrm{L}}\right)$ conservation within the lagoon can be written as:

$V_{L}\left(t_{0}+T\right)=V_{L}\left(t_{0}\right)+F_{T}^{+} T+F_{R} T$

$V_{L}\left(t_{0}+T\right) S_{L}\left(t_{0}+T\right)=V_{L}\left(t_{0}\right) S_{L}\left(t_{0}\right)+F_{T}^{+} S_{O} T$

And during the ebb-tide, the mass balance equations are:

$V_{L}\left(t_{0}+2 T\right)=V_{L}\left(t_{0}+T\right)+F_{T}^{-} T+F_{R} T$ 
402

403

404

405

406

407

408

409

410

411

412

413

414

415

416

417

418

419

420

421

422

Considering that the volume of the lagoon remains constant over a complete tidal cycle $\left(V_{L}\left(t_{0}+2 T\right)=V_{L}\left(t_{0}\right)\right)$, the total balance over the entire tidal cycle can then be written as:

$F_{T}^{+}+F_{T}^{-}+2 F_{R}=0$

$\frac{S_{L}\left(t_{0}+2 T\right)-S_{L}\left(t_{0}\right)}{2 T}=-\frac{S_{L}\left(t_{0}+T\right)-S_{L}^{e q}}{\tau}$

with

$\tau=-\frac{2 V_{L}\left(t_{0}\right)}{\delta F_{T}^{-}}$

$S_{L}^{e q}=\left(1+\frac{2 F_{R}}{\delta F_{T}^{-}}\right) S_{O}$

$\tau$ can be interpreted as the timescale of the transient salinization phase.

In steady state, $S_{L}^{e q}$ corresponds to the value reached by the salinity of the lagoon, which depends on the freshwater discharge $F_{R}$ and the fraction of seawater that permanently remains in the lagoon. Note that for a sufficiently strong river inflow $\left(F_{R}>\frac{-\delta F_{T}^{-}}{2}\right)$, the salinity in the lagoon becomes zero (because $S_{L}^{e q}$ can not be negative). In transient regime, the variation of salinity is controlled by the coefficient $\tau$, which depends only on the tidal outflow and the volume of the lagoon. Considering that the parameters defining $\tau$ and $S_{L}^{e q}$ are constant during the transient regime, equation (6) leads to:

$S_{L}\left(t_{0}+t\right)=S_{L}^{e q}+\left(S_{L}\left(t_{0}\right)-S_{L}^{e q}\right) e^{-t / \tau}$

We now apply this model to the time series of observed average lagoon salinity (Fig. 4). Considering $S_{L}^{e q}$, the salinity at steady state reached in April $\left(S_{L}^{e q} \sim 25\right.$ in 2018 and 2020, and $S_{L}^{e q} \sim 16$ in 2019), and $S_{L}\left(t_{0}\right)$, the salinity at the beginning of the transient period in November-December, we can easily estimate the timescale $\tau$ from Eq. (9) as: 
424

425

426

427

Fitting this to our dataset leads to an estimate of $\tau=30-40$ days. Considering Eq. (7) and (8), and given the volume of the lagoon in the low water season $\left(V_{L}\left(t_{0}\right) \approx 1.510^{8} \mathrm{~m}^{3}\right)$ and the ocean salinity $\left(S_{O} \approx 35\right)$, one can estimate the mean river discharge into the lagoon of $F_{R}=$ $\left(1-\frac{s_{L}^{e q}}{S_{O}}\right) \frac{V_{L}\left(t_{0}\right)}{\tau} \approx 25-30 \mathrm{~m}^{3} \mathrm{~s}^{-1}$ during the dry season of 2019 and of $10-15 \mathrm{~m}^{3} \mathrm{~s}^{-1}$ during the dry season of 2018 and 2020. Note however, that a clear salinity plateau was not observed during 2018 and 2020, suggesting that we probably underestimate the equilibrium value of salinity and slightly overestimate the river discharge for these 2 years.

Using inflow-outflow transports inferred for each of the 10 ADCP field campaigns between August 2019 and December 2020 (see Section 2), the mean outflow discharge observed during ebb-tides $\left(F_{T}^{-}\right)$varied between $-200 \mathrm{~m}^{3} \mathrm{~s}^{-1}$ for neap tides (weak tidal amplitudes) to $-500 \mathrm{~m}^{3} \mathrm{~s}^{-1}$ for spring tides (high tidal amplitudes) (Fig. 6). Thus, considering a timescale $\tau=30-40$ days, during which the mean outflow discharge $F_{T}^{-}$is on average of -350 $\mathrm{m}^{3} \mathrm{~s}^{-1}$ (Fig. 6) we can estimate from Eq. (7) that:

$$
\delta=\frac{-2 V_{L}\left(t_{0}\right)}{\tau F_{T}^{-}} \approx 0.3
$$

During the transient phase of salinization, and depending on the tide intensity, we thus estimate that a fraction of $30 \%$ of seawater entering the lagoon during flood-tide remains trapped and mixes with the fresher local water, progressively enhancing the salinity of the lagoon.

As noted above, the lagoon becomes totally desalinated when the river flow $F_{R}$ becomes higher than $\frac{-\delta F_{T}^{-}}{2}$. Thus, using the values obtained above, the critical river inflow above which no salt can penetrate and the lagoon remains fresh is $\sim 50-60 \mathrm{~m}^{3} \mathrm{~s}^{-1}$. Another 
445

446 desalinated is when the residence time in the lagoon $\left(T_{r e s}=\frac{V_{L}}{F_{R}}\right)$ is below the timescale of the

447 salinization phase $\left(\tau=2 \frac{V_{L}}{\delta F_{T}^{-}}\right)$. Overall, the simple box model suggests that in dry season, the 448 salinity of Nokoué lagoon drastically depends on the river and groundwater discharges to the

449

450

451

452

453

interesting way of interpreting the critical condition above which the lagoon is entirely lagoon. Salinity can indeed range from 0 to 35 for inflow varying respectively from $50-60$ to 0 $\mathrm{m}^{3} \mathrm{~s}^{-1}$. So weak variations $\left(\sim 10 \mathrm{~m}^{3} \mathrm{~s}^{-1}\right)$ of the river discharge during the dry season can lead to very different salinities.

\section{2}

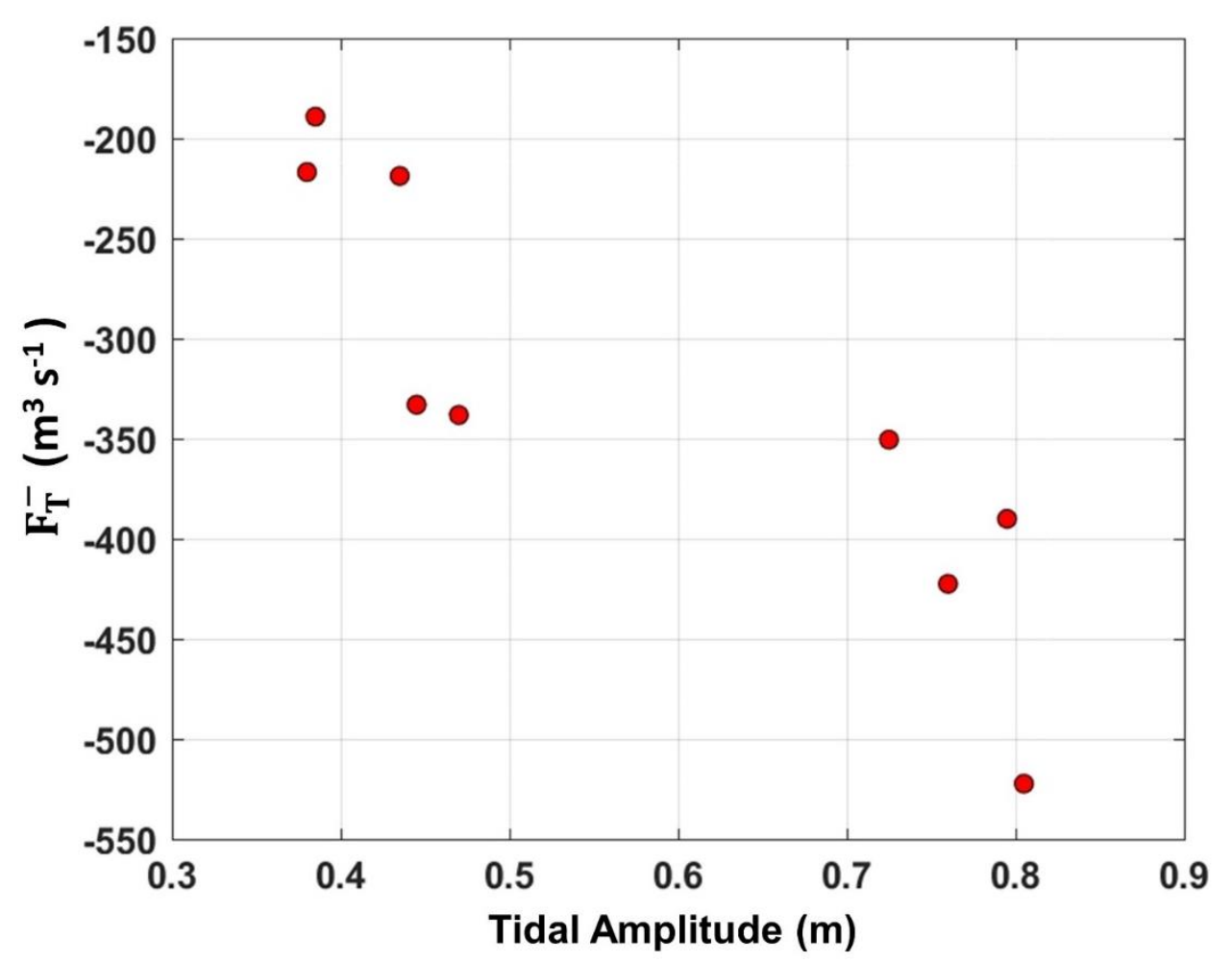

Fig. 6. Mean outflow transports $\left(F_{T^{-}}\right)$during ebb tides as a function of tidal amplitude in the offshore ocean. $F_{T^{-}}$ have been estimated from the 10 ADCP field campaigns realized between August 2019 and December 2020 in Cotonou channel, whereas tidal amplitudes have been estimated from FES2014. 


\subsection{Estimate of the baroclinic effects}

In section 3.3 we argued that the salt wedge is a sign of an important role of baroclinic effects for the penetration of salinity into the lagoon. Baroclinic effects are often neglected when modeling shallow lagoon and it is thus important to estimate this effect in the present case. To do so, we neglect all other processes (tide and river flux) and evaluate the flux associated with the baroclinic pressure gradient associated with the salinity difference between the ocean and the lagoon (Fig. 7). At the beginning of the dry season, the lagoon is fresh and the ocean salinity is $S_{o} \sim 35$. This is associated with a density difference $\Delta \rho \sim 26$ $\mathrm{kg} \cdot \mathrm{m}^{-3}$ between the ocean and the lagoon. Assuming the lagoon remains fresh, this generates a baroclinic pressure gradient between the ocean and the lagoon increasing from 0 at the surface to a maximum of $\sim \Delta \rho g h / L$ (see Fig. 7), where $g=9.81 \mathrm{~m} \mathrm{~s}^{-2}$ is the Earth gravity, $L \sim 4000$ $\mathrm{m}$ the channel length and $\mathrm{h} \sim 1.3 \mathrm{~m}$ the mean lagoon depth. .

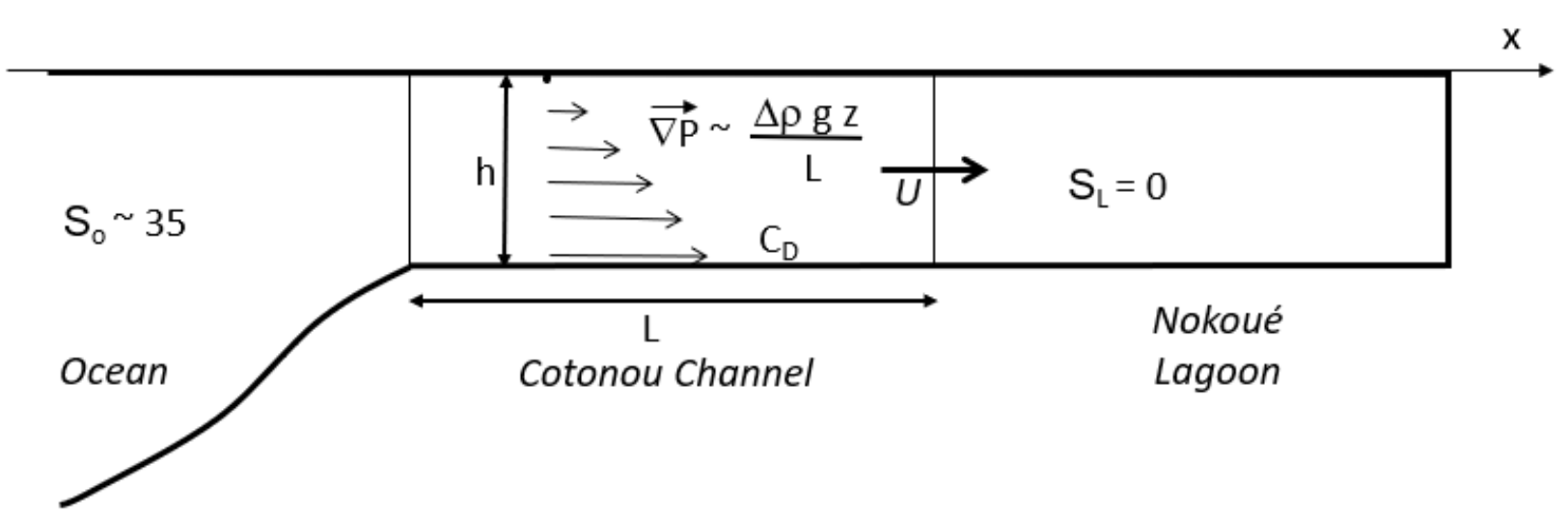

Fig. 7. Schematic (vertical cross section along the channel) of the configuration to evaluate the baroclinic effects associated with the salinity gradient between the ocean and the lagoon.

To evaluate the velocity field $U$ associated with this pressure gradient, we follow Stigebrandt (1980) and assume it is equilibrated at first order by the bottom friction in the channel (Fig. 7) which can be expressed as 


$$
\nabla P=\frac{\Delta \rho g z}{L} \sim \rho C_{D} \frac{U^{2}}{h}
$$

479

480

where $C_{D} \sim 0.004$ is the bottom friction coefficient. This gives an evaluation of the velocity field associated with the salinity gradient. Integrating the velocity profile from the surface to depth $h$ and multiplying by the lagoon breadth $l \sim 280 \mathrm{~m}$, we get the mean transport associated with baroclinic effects:

$$
T=\frac{2}{3} \sqrt{\frac{\Delta \rho g}{\rho C_{D} L}} h^{2} l \sim 40 \mathrm{~m}^{3} . \mathrm{s}^{-1}
$$

Interestingly, it is close to the critical river flux above which the lagoon will be entirely fresh $\left(\sim 50-60 \mathrm{~m}^{3} \mathrm{~s}^{-1}\right)$. The latter evaluation is a crude estimate, but it indicates that the fraction of the salinity flux entering the lagoon during the transient regime and associated with baroclinic effects is not negligible and should be considered in realistic models of the Nokoué lagoon.

\subsection{Interannual variability in dry season lagoon salinity}

To explain the observed interannual differences in dry season maximum salinity, the box model suggests that the river discharge must have been twice as large in $2019\left(25-30 \mathrm{~m}^{3}\right.$ $\left.\mathrm{s}^{-1}\right)$ as in 2018 or $2020\left(10-15 \mathrm{~m}^{3} \mathrm{~s}^{-1}\right)$. Hydrological data of the river discharge close to the coast is not available (not monitored). We therefore use CHIRPS-2.0 precipitation data (Funk et al., 2015) to confirm the most plausible cause of the reduced salinization observed in 2019 i.e. a different rainfall regime in 2019. Figure 8 shows the cumulated rainfall observed between December and April for the 3 years (2018-2020). This Figure shows that rainfall was much more abundant in the dry season of 2019 compared to 2018 and 2020, more particularly in the southern part of the Ouémé catchment and over the Nokoué lagoon (Fig. 8). Over these 5-month periods, the cumulated precipitations that fell within the Ouémé and Sô catchment 
basins were of $\sim 165 \mathrm{~mm}$ in 2018, 200 $\mathrm{mm}$ in 2019 and $\sim 150 \mathrm{~mm}$ in 2020 . The higher cumulated precipitation in 2019 must have led to a higher freshwater discharge into the lagoon and is thus likely responsible for the lower salinity values observed from January to April 2019. During this period, the lagoon was also $\sim 5-10 \mathrm{~cm}$ higher than during the dry season of 2018 and 2020 (Chaigneau et al., 2020), again suggesting a greater supply of fresh water in 2019 , as already indicated by both the box model and precipitation data. Note that from the cumulated precipitations (Fig. 8), the beginning of 2020 was likely the driest season of this 3-year period. However, salinity in 2020 was similar to 2018 (Figs. 2a-b, 4), suggesting that other processes may also affect the lagoon salinity and mixing such as wind, waves, or changes in the morphology of the Cotonou channel mouth that can modify salt fluxes.
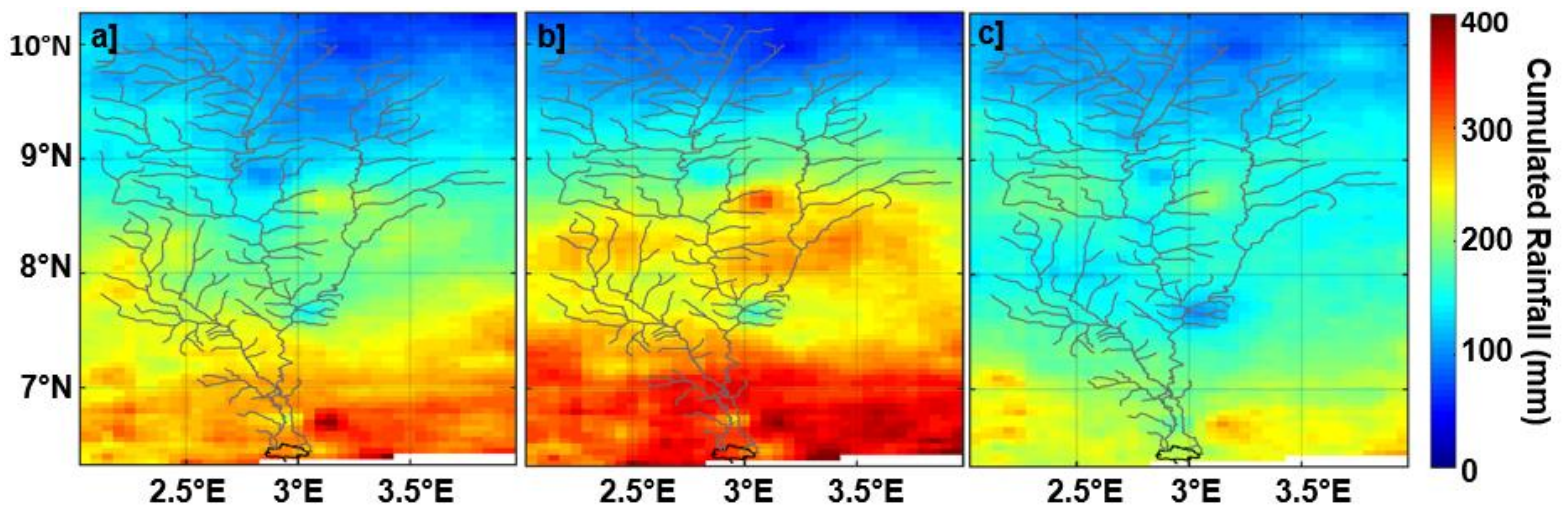

Fig. 8. Cumulated rainfall (December-April) over the Ouémé basin catchment in a] 2018, b] 2019, and c] 2020. The hydrographic network of the Sô and Ouémé catchments is shown in gray, whereas as the Nokoué lagoon is delimited in black.

Finally, at local scale, the salinity dataset has highlighted a mean salinity gradient between the North-East (minimum salinity) and the South-West (maximum salinity) of the lagoon (Figs. 2a-b). Intuitively, this stronger desalinization at the eastern part of the lagoon, may be due to a stronger discharge of the Ouémé River compared to the Sô River. Unfortunately, due to the lack of hydrological measurements in the catchment basins, the 
relative importance of the freshwater discharges from the Sô and Ouémé remains unclear. Previous studies suggested that during the dry season (December - April), the Sô discharge would be much higher $\left(\sim 30-40 \mathrm{~m}^{3} \mathrm{~s}^{-1}\right)$ than the Ouémé outflow $\left(\sim 5-15 \mathrm{~m}^{3} \mathrm{~s}^{-1}\right)$ mainly due to an excess of groundwater discharge into the Sô (Djihouessi and Aina, 2018; Mama et al., 2011; Zandagba et al., 2016b). In contrast, during the wet season, these authors indicate a stronger discharge of the Ouémé (230-340 $\mathrm{m}^{3} \mathrm{~s}^{-1}$ ) compared to the Sô (120-200 $\mathrm{m}^{3} \mathrm{~s}^{-1}$ ), due to a much larger catchment area of the Ouémé River. Thus, our results, based on salinity observations only, seem to partly contradict these previous studies, since a stronger desalinization is generally observed at the mouth of the Ouémé River all year long and in particular during the dry season (Fig. 2a).

\section{Conclusion}

Monthly salinity observations spanning three years documented the seasonal and interannual variations of the salinity and vertical stratification in Nokoue lagoon, with significantly greater freshwater influence observed in 2019.

Using a simple box model, we estimated that these interannual differences - consistent with observed rainfall variations over the lagoon's catchment - can be induced by weak variations of $10-15 \mathrm{~m}^{3} \mathrm{~s}^{-1}$ in the river discharge during the dry season. In dry season, we estimated that around $30 \%$ of the seawater entering the lagoon by tides, mixes with the fresher lagoon's water and enhances its salinity. This relatively simple model also suggests that the lagoon is completely desalinated for a river discharge greater than $\sim 50-60 \mathrm{~m}^{3} \mathrm{~s}^{-1}$. The model also provided a useful characteristic time scale $\tau \sim 30-40$ days for the salinization of the lagoon. Estimates for the desalination are similar so that the general mixing time scale of the lagoon is $30-40$ days. 
These results show that the salinity of Nokoué lagoon is very sensitive to small 54 changes in river's discharge. Additional data would be required to improve the understanding of the main forcing mechanisms involved in the observed spatio-temporal salinity variations of the lagoon (e.g. freshwater discharge, evaporation, wind and wave mixing, change in the morphology of the Cotonou channel...). Overall, the salinity data and results obtained in this study provide a useful baseline for ecosystem management purposes or to anticipate the response of this important West-African lagoon under climate-change scenarios.

\section{Acknowledgements}

Field campaigns and instrumentation were chiefly supported by IRD, with contributions from ANR @RAction chair medLOC (ANR-14-ACHN-0007-01 - T. Stieglitz). V. OKPEITCHA was funded by OmiDelta project of the Embassy of the Kingdom of the Netherlands in Benin, through a scholarship grant of the National Institute of Water (INE/UAC). This work is a contribution to the «JEAI SAFUME » project funded by IRD. Special thanks to the members and crew participating to the monthly surveys, and in particular A. ASSOGBA, M. BENOIST, and J. AZANKPO. Collaboration of Team 2/ODA-INE is also acknowledged. .

1

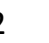

$$
3
$$




\section{References}

Adandedjan, D., Makponse, E., Hinvi, L.C., Laleye, P., 2017. Données préliminaires sur la diversité du zooplancton du lac Nokoué (Sud-Bénin). J. Appl. Biosci. 115, 1147611489. https://doi.org/10.4314/jab.v115i1.7.

Alassane, A., Trabelsi, R., Dovonon, L.F., Odeloui, D.J., Boukari, M., Zouari, K., Mama, D., 2015. Chemical Evolution of the Continental Terminal Shallow Aquifer in the South of Coastal Sedimentary Basin of Benin (West-Africa) Using Multivariate Factor Analysis. J. Water Resour. Prot. 07, 496-515. https://doi.org/10.4236/jwarp.2015.76040.

Attrill, M.J., 2002. A testable linear model for diversity trends in estuaries. J. Anim. Ecol. 71, 262-269. https://doi.org/10.1046/j.1365-2656.2002.00593.x.

Badahoui, A., Fiogbe, E., Boko, M., 2009. Les causes de la dégradation du chenal de Cotonou. Int. J. Biol. Chem. Sci. 3, 979-997. https://doi.org/10.4314/ijbcs.v3i5.51077.

Bretherton, F.P., Davis, R.E., Fandry, C.B., 1976. A technique for objective analysis and design of oceanographic experiments applied to MODE-73. Deep. Res. Oceanogr. Abstr. 23, 559-582. https://doi.org/10.1016/0011-7471(76)90001-2.

Carrere, L., Lyard, F., Cancet, M., Guillot, A., and Picot, N. , 2016a. FES 2014, a new tidal model - Validation results and perspectives for improvements, ESA Living Planet Conference, Prague, Czech Republic.

Chaigneau A., Stieglitz T., Okpeitcha V., Assogba A., Sohou Z., Peugeot C., Morel Y., 2020. Impact du changement global sur les systèmes lagunaires en Afrique de l'Ouest : le cas du lac Nokoué au Bénin. Météo et Climat Info n79 - Juillet 2020.

Chaigneau, A., Okpeitcha, V. O., Morel, Y., Stieglitz, T., Assogba, A., Benoist, M., Allamel, P., Honfo, J., Awoulbang Sakpak, T. D., Rétif, F., Duhaut, T., Peugeot, C., Sohou Z., 2021. From seasonal flood pulse to seiche: Multi-frequency water-level fluctuations in a large shallow tropical lagoon (Nokoué Lagoon, Benin). Estuarine Coastal and Shelf 


\section{Science, revised.}

Choplin, A., 2019. Produire la ville en Afrique de l'Ouest : le corridor urbain de Accra à Lagos. Inf. Geogr. 83, 85. https://doi.org/10.3917/lig.902.0085.

de Miranda, L.B., Andutta, F.P., Kjerfve, B., Castro Filho, B.M. de, 2017. Fundamentals of Estuarine Physical Oceanography, Ocean Engineering \& Oceanography. Springer, Singapore.

Djihouessi, M.B., Aina, M.P., 2018. A review of hydrodynamics and water quality of Lake Nokoué: Current state of knowledge and prospects for further research. Reg. Stud. Mar. Sci. 18, 57-67. https://doi.org/10.1016/j.rsma.2018.01.002

Dovonou, E.F., Boukari, M., 2014. Gestion environnementale des aquifères superficiels au sud-Bénin: Etat des lieux et mesures de protection, Editions U. ed. Verlag.

Funk, C., Peterson, P., Landsfeld, M., Pedreros, D., Verdin, J., Shukla, S., Husak, G., Rowland, J., Harrison, L., Hoell, A., Michaelsen, J., 2015. The climate hazards infrared precipitation with stations - A new environmental record for monitoring extremes. Sci. Data 2, 150066. https://doi.org/10.1038/sdata.2015.66

Gadel, F., Texier, H., 1986. Distribution and nature of organic matter in recent sediments of Lake Nokoué, Benin (West Africa). Estuar. Coast. Shelf Sci. 22, 767-784. https://doi.org/10.1016/0272-7714(86)90098-3

Gnohossou, P., 2006. La faune benthique d'une lagune ouest Africaine (le lac Nokoue au Bénin), diversite, abondance, variations temporelles et spatiales, place dans la chaine trophique. Université de Toulouse > Institut National Polytechnique de Toulouse Toulouse INP (FRANCE).

Gnohossou, P., Lalèyè, P., Atachi, P., Magali, G., Villanueva, M., Moreau, J., 2013. Temporal variations in the food habits of some fish species in Lake Nokoué, Benin. African J. Aquat. Sci. 38, 43-47. https://doi.org/10.2989/16085914.2013.792768 
Lalèyè, P., Niyonkuru, C., Moreau, J., Teugels, G.G., 2003. Spatial and seasonal distribution of the ichthyofauna of lake nokoué, bénin, west africa. African J. Aquat. Sci. 28, 151161. https://doi.org/10.2989/16085910309503779

Le Barbé, L., Alé, G., Texier, H., Borel, Y., Gualde, R., 1993. Les ressources en eaux superficielles de la République du Bénin, ORSTOM. ed, MONOGRAPHIES HYDROLOGIQUES. Institut Français de Recherche Scientifique pour le Développement en Coopération, Paris.

Lawin, A.E., Hounguè, R., N'Tcha M'Po, Y., Hounguè, N.R., Attogouinon, A., Afouda, A.A., 2019. Mid-Century Climate Change Impacts on Ouémé River Discharge at Bonou Outlet (Benin). Hydrology, 6 (72), https://doi.org/10.3390/hydrology6030072.

Lyard, F. H., Allain, D. J., Cancet, M., Carrere, L., and Picot, N. , 2020. FES2014 global ocean tides atlas: design and performances, Ocean Sciences Discussions, 1-40, https://doi.org/10.5194/os-2020-96.

Mama, D., 2010. Méthodologie et résultats du diagnostic de l'eutrophisation du lac Nokoué (Bénin). Thèse. Université de Limoges.

Mama, D., Deluchat, V., Bowen, J., Chouti, W., Yao, B., Gnon, B., Baudu, M., 2011. Caractérisation d'un système lagunaire en zone tropicale: Cas du lac nokoué (Bénin). Eur. J. Sci. Res. 56, 516-528.

McIntosh, P.C., 1990. Oceanographic data interpolation: Objective analysis and splines. J. Geophys. Res. 95, 13529. https://doi.org/10.1029/jc095ic08p13529

Millero, F. J., 1993. What is PSU? Oceanography, 6(3), 67.

Moriconi-Ebrard, F., Harre, D., Heinrigs, P., 2016. L'urbanisation des pays de l'Afrique de l'Ouest 1950-2010 : Africapolis I, mise à jour 2015, Cahier de. ed. OCDE, Paris.

Niyonkuru, C., Lalèyè, P.A., 2010. Impact of acadja fisheries on fish assemblages in Lake Nokoué, Benin, West Africa. Knowl. Manag. Aquat. Ecosyst. 5. 

https://doi.org/10.1051/kmae/2010033

N'Tcha M'Po, Y., Lawin, E., Yao, B., Oyerinde, G., Attogouinon, A., Afouda, A., 2017. Decreasing Past and Mid-Century Rainfall Indices over the Ouémé River Basin, Benin (West Africa). Climate 5 (74).

Odountan, O.H., de Bisthoven, L.J., Koudenoukpo, C.Z., Abou, Y., 2019. Spatio-temporal variation of environmental variables and aquatic macroinvertebrate assemblages in Lake Nokoué, a RAMSAR site of Benin. African J. Aquat. Sci. 44, 219-231. https://doi.org/10.2989/16085914.2019.1629272

Rynne, P., Reniers, A., van de Kreeke, J., MacMahan, J., 2016. The effect of tidal exchange on residence time in a coastal embayment. Estuar. Coast. Shelf Sci. 172, 108-120. https://doi.org/10.1016/j.ecss.2016.02.001.

Stigebrandt, A., 1980. Some aspects of tidal interactions with fjord constrictions. Estuar. Coast. Shelf Sci. 11, 151-166.

Texier, H., Colleuil, B., Profizi, J.P., Dossou, C., 1980. Le lac Nokoué, environnement du domaine margino-littoral sud-béninois : bathymétrie, lithofaciès, salinité, mollusque et peuplements végétaux. Bull. Inst. Géol. Bass. Aguit.. Bordeaux 28, 115-142.

United Nations Educational, Scientific and Cultural Organization, 1985. The international system of units (SI) in oceanography, UNESCO Technical papers, $\mathrm{N}^{\circ} 45$, IAPSO Sci. $\mathrm{N}^{\circ} 32$, Paris, France.

Wong, A.P.S., Johnson, G.C., Owens, W.B., 2003. Delayed-mode calibration of autonomous CTD profiling float salinity data by $\chi$-S climatology. J. Atmos. Ocean. Technol. 20, 308318. https://doi.org/10.1175/1520-0426(2003)020<0308:DMCOAC>2.0.CO;2

Yehouenou, E.A.P., Adamou, R., Azehoun, P.J., Edorh, P.A., Ahoyo, T., 2013. Monitoring of heavy metals in the complex "Nokoué lake - Cotonou and Porto-Novo lagoon" ecosystem during three years in the Republic of Benin. Res. J. Chem. Sci. 3, 12-18. 
71

Zandagba, J., Adandedji, F.M., Mama, D., Chabi, A., Afouda, A., 2016a. Assessment of the Physico-Chemical Pollution of a Water Body in a Perspective of Integrated Water Resource Management: Case Study of Nokoué Lake. J. Environ. Prot. (Irvine,. Calif). 07, 656-669. https://doi.org/10.4236/jep.2016.75059

Zandagba, J., Moussa, M., Obada, E., Afouda, A., 2016b. Hydrodynamic modeling of Nokoué Lake in Benin. Hydrology 3, 44. https://doi.org/10.3390/hydrology3040044 